„Bohemistyka” 2020, nr 4, ISSN 1642-9893

Jindřiška Svobodová

DOI: $10.14746 /$ bo. 2020.4 .3

Palacky University

\section{Political Dialogue as Room for Verbal Aggression ${ }^{1}$}

Keywords: media communication, online communication, im/politeness, verbal aggression, face, face threating act

\section{Abstract}

The author analyses two specific communicative events within the political discourse in the current work. The analysis involves a dialogue between two politicians who meet face to face in a TV studio and the subsequent communication taking place on the Internet after the dialogue was made public.

The utilization of offensive communicative strategies is a typical feature in political media communication where a communicating party attacks the communication counterpart with the intention of challenging his/her positive face and emphasizing his/her negative character traits in front of potential voters, while at the same time emphasizing his/her own positive values. For this reason, the author analyses the individual strategies employed by politicians with this intention in a particular communicative event.

The work provides an entire chapter dealing with strategies used by participants in an Internet discussion. In this case, the communication takes place among speakers who do not know each other, so the aim of the work is to investigate whether attacks against one's face take place even in this kind of communication, and if so, what personality traits of the communicants are attacked.

\section{Politeness as a Pragmalinguistic Phenomenon}

Pragmalinguistic and sociopragmatic research is a linguistic field which has been developing extensively over the last half century. An analysis of language in its current use often involves research into

1 This treatise was supported with financing received from the FPVČ fund granted by Palacký University Olomouc, Faculty of Arts, in the years 2016-2020. non/politeness strategies and their contribution to successful communication. The concept of politeness also carries two different meanings: a concept studied by linguists at the theoretical level, and a tool employed by lay language users in evaluation of communication partners. Communicants relate the assessment of their speeches as polite or impolite, in relation to their own experience context and perception of politeness. The very same utterance, evaluated by some of the parties to the speech act as polite may, nevertheless, be rejected by others as manipulative, insincere or too formal.

The emphasis on evaluating a speech as im/polite with regard to the communication effect achieved demonstrates, according to Wolfram Bublitz (2009, p. 259n.), that a linguistic means of expression cannot be assessed as polite or impolite in and of itself, hence inherently, although it is obvious that some, such as diminutives, modal verbs or conditionals, are typical for politeness strategies and perceived as more appropriate to achieve the desired communication intent (Oh wait! Could you please let him know that... etc.). Operating with 'conventional politeness', Gabriele Kasper (2009) argues that its instruments involve standardized routine phrases used in greetings, praises or requests, and means of social deixis, including the use of different forms of address reflecting social standards and hierarchy.

The pragmatic turn in linguistics and interest in language in its current use have led to a growing interest in research into language interaction, the relationship of communicants, and the circumstances of achieving communication goals since the 1970s. Language interaction was perceived as purposeful and strategic conduct (concept of Max Weber), and classical definitions regarded politeness primarily as a way to avoid conflict, to reduce tension and aggression between communicants and minimize manifestations of mutual antagonism. According to Geoffrey Leech (1980, p. 19), "Politeness is a strategic conflict avoidance," while Kasper (1990, p. 194) defines it as "The strategies available to interactants to defuse the danger and to minimalise the antagonism," and Robin Lakoff (1973, p. 64) as "Politeness is developed by societies in order to reduce friction in personal inter- 
action." The purposefulness of politeness strategies is highlighted in particular by Penelope Brown and Stephen Levinson (1978 and 1987):

"Politeness is a complex system for softening face-threatening acts." The above concepts conceived of interpersonal interaction as a potentially threatening or offensive act and politeness as an aggression management strategy.

Viewed from the opposite perspective, politeness is a way of developing and maintaining good relationships and a friendly atmosphere. Politeness strategies can also be viewed positively as a way of expressing mutual support, efforts to show mutual respect and meet cultural and situational expectations. Politeness can thus be defined both negatively as efforts to avoid conflicts and reduce aggressive communication potential, and positively as a means of strengthening good relations between communicants (see Zítková 2008, p. 47).

Linguistic research on politeness in the second half of the last century therefore stemmed primarily from this purpose-based concept. The cornerstone for the majority of researchers was the cooperative principle, the essence of which was defined by Paul Grice (1975, pp. 45-46) as follows: "Make your conversational contributions such as is required, at the stage in which it occurs, by the accepted purpose or direction of the talk exchange in which you are engaged." Grice used this principle to derive four cooperation maxims (quality, quantity, relevance, and manner), devised as imperatives:

1) Maxim of quality - Try to make your contribution one that is true.

a) Do not say what you believe is false.

b) Do not say that for which you lack adequate evidence.

2) Maxim of quantity

a) Make your contribution as informative as is required (for the current purposes of the exchange).

b) Do not make your contribution more informative than is required.

3) Maxim of relevance

a) Be relevant.

4) Maxim of manner - Be perspicuous a) Avoid obscurity of expression.

b) Avoid ambiguity.

c) Avoid unnecessary prolixity.

d) Be orderly.

This principle, however, is more acceptable as a philosophical concept, and would be difficult to observe unconditionally in everyday communication. Communication is never interpreted at the level of comprehension of literal meanings. As Dan Sperber and Deride Wilson (1986, p. 66) point out, communicants enrich the interpretation with their own interference from earlier communication interactions, and inferential comprehension is one of the key thought processes. The authors highlight the significance of context, which aids full comprehension. Their theory of relevance is grounded on the following maxim: "Every act of ostensive communication communicates the presumption of its own optimal relevance" (1986, p. 158).

In analogy with Grice's cooperative principle and conversational maxims, Leech (1983) defined the politeness principle, based on which communication is expected to minimize the expression of impolite beliefs and maximize the expression of polite beliefs. This politeness principle regulates the relational aspect of language interaction, and Leech places it above the cooperative principle. Similarly to Grice, Leech (1983) draws the following politeness maxims from the principle: Maxim of Tact, Generosity, Approbation, Modesty, Agreement and Sympathy. All the maxims were once again formulated as imperatives, calling on minimizing disagreements, discord or benefits and the self-praise of the speaker, and maximizing agreement, compliance, and the benefit and praise of the recipient. Leech's concept was later criticized, particularly for being anglocentric, although Leech himself never claimed the principle to be universal. Only the Grand Strategy of Politeness was deemed universal - in order to be polite, a speaker should, according to this strategy, maximize the importance of the communication partner while minimizing the importance of themselves.

Pragmalinguistic research, inspired by Leech's politeness principle, led to a series of studies focused primarily on the means of expression used to implement maximization and minimization strate- 
gies. The approach ultimately led to generalization and absolutization, and politeness was perceived as an inherent and stable part of a specific linguistic means. Depending on the context and existing relational network, however, the means perceived as typically "polite" (e.g. diminutives) may become a tool of verbal aggression (Do I have to repeat myself, Missy? We're closed).

The politeness principle of Robin Lakoff (1973, p. 64) appears more universal. It advocates the following principles: Do not impose, Give options, Make the addressee feel good - be friendly. An inspiring combination is Grice's conversation principle summarized in the request 'Be clear!' and Robin Lakoff's politeness principle summarized as 'Be polite!', which Lakoff defined as 'pragmatic competence' (Lakoff 1973).

The concept of Penelope Brown and Stephen Levinson (1978, 1987) shares a number of characteristics with Leech's theory. Their concept does not take into account the social dimension of the communication act and interprets politeness as the strategic conduct of the speaker aimed at saving the face of the addressee and ultimately the speaker themselves. Face is understood as a context-independent self-value. The concept also considers politeness an inherent part of the meaning of selected means of expression. It is not the result of discursive negotiations. A key factor in assessing a communication activity as $\mathrm{im} /$ polite is the intention of the speakers, who reflect on the possible impact of their opinion of the addressee. The use of politeness strategies is only motivated by the efforts of the speaker to prevent, mitigate or offset conflict-triggering threats to the addressee's face. The speaker saves the addressee's face in order not to jeopardize the status quo.

This concept of face is currently being rejected, and critics are reverting to the original concept of Erving Goffman, who characterizes face as a dynamic social construct which changes depending on the context of interaction. Face as a claimed self-evaluation is negotiated and assigned during each social interaction with regard to the context. Goffman's "sociocentric" perspective involved the recognition of the role of the participant in the social hierarchy and thus their social identity (the concept of face is discussed in more detail in the section analysing specific communication interactions).

Recent studies of politeness, sometimes referred to as discursive or postmodern, emphasize in particular the relational and contextual aspect of politeness. They indicate that the assessment of an utterance as $\mathrm{im} /$ polite always depends on context and stems, from the perspective of all participants, from a particular language interaction. As Richard J. Watts (2003) points out, it would be simplistic to focus research solely on producers and their intent, as it would neglect the fact that the assessment of an utterance as acceptable or unacceptable is subject to negotiation between all the parties to a communication act (the analysis includes their verbal as well as nonverbal activities).

The following part of the work, conceived as a case study, focuses on the differences between the attack strategies used in two different types of communicative events. Both belong to a wide branch of political discourse. One took place between active "professional" politicians and was executed in the form of a media dialogue, while the other communicative event took place in a group of mutually unfamiliar anonymous communicants in the environment of an Internet discussion. The aim is therefore to find out whether communicants in both types of social interactions use aggressive strategies and if so, what identity features of the communication partners are attacked.

\subsection{Impoliteness and Verbal Aggression in Political Dialogue}

The following section focuses on a communicative event that took place in the media environment and belongs to texts of political discourse. ${ }^{2}$ A typical feature of this type of communication is that it takes place regardless of the interests and intentions of the communication

${ }^{2}$ In the context of this treatise, a discourse does not refer to an isolated text, but rather to part of a social interaction; in a wider sense, it even involves the particular communicants and the immediate context. The discourse is related to a strictly delimited group of users, is related to a particular social or communicative event (or 
partner, and is at the same time focused especially on enforcing the producer's own interests. The forms of strategies used by communicants to accomplish it range from openly attacking to covert ones. Such communication involves regular threatening of the counterpart's face and downgrading the positive values he/she attributes to himself/herself and intends to use for self-presentation in public.

A typical feature of communication within political discourse is ruthless enforcement of one's own intentions to the detriment of a communication partner. In this regard, we may even facetiously claim that a politician is considered skilful and successful particularly due to his/her ability to draw attention, persuade, and in extreme cases even manipulate the recipient - de facto the potential voter. The transmitter needs to persuade the receiver that they both share the same interests, that the concerns faced by "common people" are identical to his/her concerns, and that there is an obvious mutual unity of opinion between the transmitter and the receiver. The positive perception of a particular politician is also directly dependent on the ability to persuade the recipient that the politician would not hesitate to make a public appearance advocating and defending the common interests and take a determined and uncompromising approach.

An attack against the face of a political opponent, concerning manifestations of impoliteness and verbal aggression, is therefore a common and even logical element of communicative events within political discourse, and it is therefore difficult to apply the principles of politeness that are commonly observed in daily communication. In general, determining what kind of behaviour or verbal expression is polite or impolite is not easy. As stated above, Robin Lakoff (1990, p. 34) defines politeness as a system of human relationships estab-

a social institution), and addresses a particular topic or a group of (usually) mutually related topics. Communication within a discourse follows specific rules that are established particularly within standard situations. The political discourse is therefore perceived as an intricate complex involving not only the communication taking place among politicians, but also its interpretation and evaluation from communicants who are not active politicians (but keep a keen interest in it, e.g. voters). lished with the purpose of minimizing the conflicts and confrontations that are potentially present in every human interaction. So while from this socio-pragmatic perspective, politeness is understood as a facilitating phenomenon, i.e. a phenomenon enabling efficient communication, in the context of politics, impoliteness is not considered an interactional deficiency, and a communicant enforcing ruthlessly his/her own (and proclaimed voters') interests is more likely to be evaluated as a successful one.

\subsection{Intentional Impoliteness}

Aggressive communicative behaviour focused on harming the communication partner is usually investigated within research into impoliteness. Impoliteness is difficult, however, to grasp as a pragma-linguistic phenomenon, as it covers a wide range of communicative behaviour from a frequently unintentional lack of politeness to intentionally offensive and harmful behaviour. In addition, assessment of communication as polite or impolite changes over time and is also highly dependent on each communicant's individual perception. The difference between politeness in the pragma-linguistic and the socio-pragmatic contexts, as defined by Leech (2014, p. 217), is also an important aspect. In both cases, an utterance may be assessed according to its rating on a value scale, but each of the types of politeness works with different interfaces. The pragma-linguistic scale begins with the zero point and is unidirectional. An utterance may be assessed as a more polite or even more polite one (non polite $\rightarrow$ more polite $\rightarrow$ even more polite $\rightarrow$...) and according to Leech (2014, p. 18) the zero point is an utterance without any means of expression whose utilization would indicate the effort for expressing a polite evaluation or attitude. The original treatise labels such an utterance as non-polite as opposed to an utterance that is impolite. So with regard to terminology, the cases where politeness is not manifested with verbal means (i.e. zero politeness) are distinguished from cases where elements indicating impoliteness are obviously manifested. 
The socio-pragmatic scale of politeness is two-directional, the zero point is located in the middle, and utterances are assessed as polite and impolite according to context-dependent factors involving a complex relational network reflecting the proximity of communication partners, their age, gender, social status, social asymmetry, etc. The band of "zero" politeness is represented with utterances that could be labelled as "appropriate", "normal", or "standard" (with regard to the circumstances under which the communication takes place and the communication context). Regarding the communication standard, the individual utterances may be assessed as insufficiently polite (underpoliteness), or exceedingly polite (overpoliteness) (Leech 2014, p. $218) .{ }^{3}$ Even an utterance that does not include any elements of rudeness or vulgarity and thus could be assessed as a neutral one with respect to the means of expression could be socio-pragmatically intended as an attack against the face of communication partners and as such be assessed as a clearly impolite one:

[1]

Presenter: How far are you willing to go with the quorum to consider a referendum as a valid one?

Tomio Okamura: Well, I would like to say that there has already been a vote on our proposal in the Chamber of Deputies, which was crucial, and it was not rejected. The Chamber voted and its condition was holding a workshop where members of other parties would be informed what a referendum actually is. I was taken aback a bit. I thought they knew it. $[\ldots]^{4}$.

This politician, a long-term representative of an opposition party with a significantly populistic programme, uses the space provided to him to answer a question as to what quorum his party would be willing

\footnotetext{
${ }^{3}$ M. A. Locher and J. R. Watts (Locher, Watts 2005, p. 12) point out that the assessment of the absolute degree of $\mathrm{im} /$ politeness is significantly problematic, and emphasize the importance of the context of the communicative event and the relationship between the communicants.

${ }^{4}$ In transcriptions of spoken utterances, we do not aim to capture their suprasegmental qualities, and only indicate possible simplified pronunciation (in italics) and emphasis (in capital letters).
}

to accept in the voting on the general referendum in the Parliament in order to point out the political ignorance and incompetence of politicians from other political parties. In the dialogue, he avoids answering a direct question posed by the presenter and instead of presenting the requested facts, presents the qualities of his own party (its key proposal was not rejected) and points out the imperfections of opposition deputies. This strategy, based on violation of Grice's maxim of quantity, enabled him to demonstrate his own positive values in front of the spectators/voters - he and the members of his movement not only proposed a bill that passed the first reading, but his political knowledge exceeds the common standard.

In order to assess the utterance as a polite or impolite one, it is important to know the context in which the utterance was produced; in addition, its entire pragmatic meaning is time-dependent and inconstant. Another factor playing an important role is also obviously the interpretation activity of the participants of a communicative act, so the classification of an utterance as a polite or impolite one as perceived by the individual communicants may vary. Miriam Locher and Richard Watts use the concept of the so-called relational work which is superordinate to impoliteness; it is a mechanism capturing the entire range of interpersonal aspects in communicative interaction. Locher and Watts $(2005$, p. 11) point out that the range of verbal means of expression used to fulfil communicative strategies is very wide - from openly impolite, rude and aggressive communication through neutral communication to polite communication expressing esteem and respect. The assessment of utterances, however, always needs to involve the aspect of so-called appropriateness and communicative behaviour is evaluated in relation to established social norms and acquired communicative frameworks. Impoliteness is commonly related to violation of existing social and communicative norms and with threatening the addressee's face.

\subsection{Impoliteness as an Attack Against Face}

The concept of face in the linguistic field of pragmatics is long established (Goffman 1967) and at present, there are various concepts of 
face. The original concept is based on the fact that every participant in communication enters a social interaction with a certain self-evaluation and expects to be perceived by other participants of this interaction adequately with regard to this self-reflection. Apart from this so-called positive face, the participant also has negative face related to the fact that the participant wishes not to have his/her communicative behaviour limited, be interrupted or forced to participate in an activity that could be discomforting or could potentially do him/her some kind of harm in front of others - in other words, the participant claims his/her own personal freedom and space. Erving Goffman (1967, p. 31) considers face to be a result of social interaction, as a positive social value that a speaker demands from the partners in a particular communicative event. It is in fact a way in which the speaker desires to be perceived and evaluated. Face is established in the course of communicative interaction, and in a broader sense even social interaction, so it is a self-reflection, an image the speaker establishes in a particular situation that has certain characteristic social attributes - it is a "relational value". This also means that depending on the type of social interaction entered by the individual as well as on the changing circumstances of the communicative event, the individual may claim a varying number of faces (in some situations it seems more important to present oneself e.g. as a responsible father, or as an uncompromising businessman, an incorruptible politician, etc.). So basically, it is a mask taken and changed by the speaker according to the role he/she is performing in a particular situation (Locher, Watts 2005, p. 12).

Similar starting points are adopted by Helen Spencer-Oatey (2007, p. 640): for her, the key aspect necessary in order to define the concept of face is its connection to identity. The concept of identity involves a very wide range of qualities and characteristics including e.g. personality traits, abilities and skills, typical behavioural patterns, the adopted ideology, a particular social role and affiliation with certain groups. Based on context, these personal qualities are attributed various meanings, and their perception as positive or negative, fundamental or marginal is variable. Nevertheless, the relationship to a certain social group and a social role played by the communicant in a particular situation always come into play.

Purposeful impoliteness typical particularly in political communication is not motivated primarily by interpersonal relationships between communicants (although we naturally do not reject the possibility), but rather by their affiliation with various political parties and subjects, and as is obvious from the above presented example, the qualities attacked most frequently are those that impair the image of "a good politician".

Impolite behaviour is therefore typically accompanied by threatening face, and takes place if other communicants prevent their communication partner from presenting himself/herself in a way he/she would desire, and refuse to accept the positive social or personality attributes he/she intended to use for self-presentation - in other words, they do not accept the "mask" the partner intended to put on in the particular role. The treatise will observe what aspects of positive face are attacked by the communication partner.

\subsection{Impoliteness or verbal aggression?}

As manifested above, impoliteness is often not the result of the speaker's deliberate actions. He/she may not have intended the utterance to be impolite, but the recipient-addressee of the message embeds it into his/her own interpretation frameworks, applies previous experience and his/her own expectations, and as a result labels it as an impolite one, the reason being for instance the unintended insufficient politeness.

It is important to distinguish this non-intentional type of impoliteness from the cases of intentional attacks against the identity and face of a communication partner that are part of the offensive communicative behaviour aimed at ruthless enforcement of the producer's own intentions and goals. Within this category, it is appropriate to distinguish between impoliteness and verbal aggression. Aggressive behaviour may be manifested directly (name-calling, threatening, ridicul- 
ing, etc.) as well as indirectly (e.g. slander and mockery behind one's back). Aggression is rooted in the instinctive need for protecting oneself, one's own territory, and possibly the individual's close ones. Over the course of the development of human society, these instincts were regulated with ethical and moral norms and the ability to control the aggressive impulses has become part of the socialization process. If forced by circumstances, however, these norms are violated and avoided (for more detailed information on this topic cf. Lorenz 1969, pp. 247-262).

Verbal aggression as part of broadly perceived aggressive behaviour (Nakonečný 1999, pp. 121-124) may emerge as an impulsive reaction to an external stimulus. The goal of this impulsive aggression is to annihilate, eliminate or damage the object posing an immediate threat to the communicant. In contrast, so-called instrumental aggression extends beyond the immediate situation. The speaker is not aggressive because of an immediate threat; he/she is well aware that the aggressive behaviour will bring him/her a certain future advantage. The intention of the speaker may therefore be either to cause immediate harm to the addressee and threaten his/her self-esteem, or gain a certain future advantage for himself/herself, e.g. to strengthen the position within a group, gain admiration, force the addressee to do something, etc. In these cases, aggression is always an intentionally implemented communicative strategy, even though the means utilized involve much more than only expressive (especially rude) or otherwise marked verbal means of expression.

Verbal aggression as a strategy often appears in primarily conflict situations where the ruthlessness of the communicants is tolerated or even expected. The character of the communicative or social situation also entails the relativization of the degree of harm to the attacked subject. In political communication, for example, where aggression is in fact expected, it may be used as a tool for creating the image of a successful politician (as a decisive, brave, and swift advocate of the proclaimed values), whose qualities are shown especially in comparison to the qualities of a communication partner. With political communi- cation, the initiation mechanisms of verbal aggression are related to the character of the communicative event, and the harm to the attacked subject is also rather symbolic.

\section{Analysis of an Actual Communicative Event}

The material for analysis was acquired by transcribing a media debate involving two politicians taking place on 23 March 2018, on the public service broadcasting company Česká Televize [Czech Television - С̆ T] at the station С̆T24 within the programme Události a komentář [Events and Comments]. ${ }^{5}$ The particular dialogue was selected due to its conflict potential - one participant was Tomio Okamura, the chairman of the movement Svoboda a prímá demokracie [Freedom and Direct Democracy] (SPD), ${ }^{6}$ and the other was Dominik Feri, a Deputy for a traditional political party TOP $09 ;{ }^{7}$ both politicians have been addressing the discussed topic (the act on a general referendum) over the long term and have adopted different attitudes to it.

The debate was also made available at the YouTube channel, where it is followed with an online discussion. This treatise aims to focus both on the moderated dialogue of the two politicians and the comments in the related internet discussion.

${ }^{5}$ The channel ČT24 is dedicated primarily to political news and opinion journalism. The programme Události komentáře is a regular analytical programme where presenters of the main news bulletin elaborate and comment on a current political topic. They invite politicians from the opposite edges of the political spectrum into the studio, and the guests are always engaged in some way in the topic addressed.

${ }^{6}$ Tomio Okamura has been active in politics since 2012. The movement SPD was established in 2015; it is a populist grouping that claims to be advocating "patriotism", euro-scepticism, and stricter immigration-related legislation. It refuses to tolerate "maladaptive groups". Its representatives aim to accomplish their political goals by enforcing direct democracy; they have long been promoting the referendum act, the direct voting system, and the revocability of politicians.

${ }^{7}$ Dominik Feri works in the Chamber of Deputies of the Parliament of the Czech Republic on the Constitutional Legal Committee, and in contrast to the other guest, criticises the act on general referendum and the direct election of mayors. 


\subsection{Communicative Event}

A dialogue between politicians belongs to the group of public institutional political debates. An important factor influencing the course of the particular dialogue is the fact that it is conducted on several planes. On the first plane, there is the immediate communication between politicians, but the main aim is to mediate the communication to other recipients, to whom it is actually addressed -i.e. to spectators (in fact the future voters), and this fact in particular entails the aggressive potential of such dialogues. Intentional offensive strategies are prevalently instrumental, i.e. they are usually not entirely spontaneous (there is often no personal animosity between the particular politicians), and their utilization is related to the planned long-term establishment of the politician's face. The politician intends to demonstrate to the voters not only his/her own bravery and courage to take up a political battle, but also swiftness, erudition, etc. Public political debates frequently involve a presenter, who takes the role of a representative of a media institution who has been delegated to organize and manage the debate. The presenter's role is not negligible: the eventual effect of the communication is significantly influenced e.g. by how much time he/she provides for the contributions of the individual politicians and whether he/she firmly insists that the politicians actually answer questions, etc.

The development of modern communication technologies has brought about the emergence of a new communication plane, socalled online discussions. As already mentioned above, television spectators have always been important participants in the communicative event, but in the past, they did not participate in an active way. The only influence they had on the debate was that politicians formulated their speech taking into consideration that spectators were watching them and that their speech may influence e.g. their decision-making in upcoming elections. In contrast, spectators now have the opportunity to participate actively depending on the type of programme, either by entering a discussion via a chat and directly asking politicians, or by subsequently commenting on their media appearance in online discussions. Access to online platforms is essentially unlimited, the communicants may freely express their opinions on all topics without being restricted in any way by the presenter (whose tasks within media communication include e.g. selecting the topics, ensuring turn-taking in the debate, etc.). This leads to an increased ratio of non-professional speakers in the public space having the opportunity to express their own opinions without the risk of losing face (their face would potentially be threatened in open face-to-face communication). Their communication activity has two forms: evaluation of the watched content and reaction to the politician's media appearance, and in addition, mutual reactions to one another and participation in virtual dialogues. The result is a division of the communication activity into two types some communicants comment on the watched content, while others actively engage in dialogues. Online communication is therefore not limited in the number of communicants or the time of its existence replies and reactions may appear over a very long period of time (in this particular case, almost two years have passed from the TV broadcast, but the last comment was posted one week before the material was acquired).

\subsection{Face-to-Face Communication}

Impolite and aggressive communicative strategies are related to attacks against face. Culpeper's (1996) concept of impoliteness is based on an older distinction between positive and negative face, and it analogically distinguishes between positive and negative impoliteness. Positive impoliteness uses strategies targeted at causing damage to the positive face of a communication partner - e.g. openly expressing disinterest in topics presented by him/her, addressing topics while being aware that the communication partner feels uncomfortable about them or that they are sensitive for him/her, using expressions that the transmitter considers incomprehensible to the receiver, diminishing or humiliating the receiver using marked forms of address, etc. 
Negative impoliteness is related to intentional intimidation, mocking or belittling, as well as to openly expressing information that is considered private or intimate by the receiver, emphasizing one's own supremacy, etc.

In his later work, Culpeper (2011) works, however, with one generalized concept of face, and similarly to Spencer-Oatey (see above), connects it with various aspects of the individual's identity (e.g. aspects of relationships, social identity, etc.). From this point of view, those utterances that are used by the speaker to attack the addressee's face are impolite and aggressive. During such an attack, social norms are violated, and the result of the attack is harm, offense, or denigration of the addressee.

In the ideal scenario, the basis of verbal expression within the political discourse is the utilization of appropriate argumentation. It is not sufficient for these speakers to only describe and label a situation; in addition, they are expected to manifest the ability to provide reasoning for their attitude, to support or explain it, and analogically, if rejecting the opponent's attitudes, they are expected to protest, object to it, etc. (Švandová 1999a, p. 101). A particular argument usually consists of two main components - a premise and a conclusion. The premise is understood as an assumption, a starting point aimed at supporting the argumentation, and the conclusion is actually what we claim. As a rule, however, politicians follow the scheme If $A$, then usually $B$, even if there is no connection between the two phenomena based on a causal relationship between "the cause and the consequence". The speaker thus suggests an interpretation "if a politician does so and so, then it is certainly true that... (any negative claim about the adversary)".

In fair argumentation, speakers always seek logically correct arguments that should be relevant (ad rem) instead of threatening the communication partner or attacking his/her personal dignity (ad hominem). In contrast, argumentation in political discourse is often led so as to attack certain aspects of the adversary's identity and is based on an effort at discreditation of his/her personal or professional qualities.
In the investigated case, the politicians met to discuss a topic about which they have long had different attitudes. The policy of the SPD movement is based on enforcing elements of so-called direct democracy, while TOP 09 promotes representative democracy (where the execution of democracy is delegated to politicians elected in democratic elections).

In the observed communicative event, the strategies of Dominik Feri were in all cases based on ad rem argumentation:

[2]

Dominik Feri: After all, our Constitution states in Article 2 that it is the people who are the source of all the state's power and that they exercise it through particular bodies, which is representative democracy. In the next paragraph, however, it clearly says that Parliament may determine when the people shall execute the power directly. This means, YES, OF COURSE, direct democracy is a due complement of representative democracy - that is, at the local or regional level, undoubtedly, and also maybe in the case of some crucial issues if the Parliament makes such a resolution, but in such a general way it is completely unacceptable for us.

He built his positive face within the debate by systematically answering clearly and accurately, and formulating his statements like an expert in the particular field. He conducted an open attack against the opponent's face only twice:

1) by u sing i r o n y (Mr. Okamura spoke about the zero quorum, but he considerately concealed that the existing act on local referenda determines that ...) and adding information omitted by the political opponent in his answer, and

2) by criticising the opponent for constantly and systematically not answering the questions asked by the presenter (I will make an attempt so that at least one person in this studio answers the questions in the way they are asked).

The other guest, Tomio Okamura, used the space provided to him in the studio primarily as an arena for an open political fight. His strategy was to present himself and his movement as the bearers of positive values and to contrast his own positive features with the deficiencies of the negatively presented group of "the others": we are the only 
party in the Czech Republic that promotes the shift to ACTUAL democracy; we are simply democrats and we think that citizens are competent, and in contrast, it is clear that Kalousek's TOP 09 does not want to accept direct democracy; WE want it. Tomio Okamura builds up the face of "a people's politician" who identifies with ordinary people and promises that together they can fight politicians who, in his interpretation, represent the negatively evaluated group of elites:

[3]

Tomio Okamura: [...] because consider that in the present-day representative democracy, if someone wants to tell me that the people with a more responsible approach to the government of this country are JUDr. Bohuslav Sobotka, it is quite relevant at present, JUDr. Stanislav Gross, MUDr. David Rath, and others, so they were, that is the product of the elites. And let's say it plainly that the things they did would never have been approved of by the masses of citizens in a referendum. Take for instance the privatization in the 1990s or Klaus's amnesty and so on.

His argumentation against the political adversary is based primarily on two strategies. One of them is assertively repeating the assumption that the only actual democracy is the one executed by the people in a referendum, while the other one is denigration of individuals with different beliefs and values.

2.2.1 He explains the advantages and benefits of his own political beliefs with an argument based on authority (in greater detail Švandová 1999b, p. 146): within this strategy, the credibility of a statement is supported with the authority of the person the speaker is referring to. In order, however, for such argumentation to be legitimate, the statement needs to be supplemented with a precise reference to the source of the statement, so that the addressee may verify that there has not been any shift in the interpretation of the quote. In Tomio Okamura's utterances, this originally legitimate argument is linked to a false argument ad ignoratiam (Švandová 1999b, p. 165), where the speaker uses an unreferenced statement or consciously misuses the fact that the addressee does not have a sufficient amount of information readily available in order to correct the statement:
[4]

Tomio Okamura: ...oh please, it was even promoted by Masaryk, so back to the Czech Republic. Even Masaryk promoted direct democracy. You certainly learnt about it at school... (towards Dominik Feri)

Presenter: How many referenda took place during the period of the First Republic? Tomio Okamura: Well, he could not get it approved by the Parliament, because the Parliament was against it, so...

A similarly inconclusive case is the reference to "neighbouring countries" where the adoption of elements of direct democracy has had an unambiguously positive effect: without mentioning which countries the politician is referring to, he argues about the significant economic benefit of these measures:

[5]

Tomio Okamura: Everyone has a different programme; there is nothing wrong about that - you even admit it! But we think that the... that this strengthening of the direct accountability of politicians leads to a higher level of democracy - also, the budget is more economical and politicians care much more about money management. By the way, yes, that's the economic aspect.

Presenter: Well, and when you have mentioned some inspiration from abroad, tell me once more... it is not the first time you are asked this, but I have to pose the question... Is it actually possible to involve Switzerland in the reasoning when Swiss people are not the ones who live in this country?

Tomio Okamura: We do not use Switzerland for reasoning at all. A moment ago, I mentioned NEIGHBOURING countries around the Czech Republic...

Presenter: So, in Slovakia, their experience with referenda is that in fact they... Tomio Okamura: Well, they have very high quorums. That is why it does not work.. For example, that is the reason why TOP 09 tries to make the referenda in fact impossible.

Tomio Okamura (further): [...] This would bring huge savings to the state, streamlining of state administration, and of course eventually maybe even higher pensions, because really enormous billions will be saved; there may be even higher support for people with disabilities, and we want all that.

2.2.2 When communicating with the political opponent, Tomio Okamura used false argumentation strategies directed ad hominem, i.e. attack directed against the opponent's personality. A strategy employed several times was the one based on emphasizing the politici- 
an's youth (and therefore even his lack of experience) and education. This aspect is part of Okamura's long-term strategy of dividing society into "us" - i.e. the group of "ordinary" people without any social privileges, and the group of "the others" - i.e. the above-mentioned elites:

[6]

Tomio Okamura: You are perhaps too young, but there has already been one referendum in the Czech Republic; it was the only one, in 2003, and it was the referendum concerning the accession of the Czech Republic to the EU, so please, that is where you should learn something about it

[7]

Tomio Okamura: We took the national referendum that has taken place as a muster, and local referendum is a different legislation; you know it very well - according to my information you are studying at the Faculty of Law, so please, present the information correctly

Tomio Okamura used both these strategies in a connected way when he was attempting to establish a contrast between his own positive values as an experienced and successful politician actively advocating the interests of "ordinary people" and the lack of experience and textbook knowledge of his opponent:

[8]

Tomio Okamura: This would bring huge savings to the state, streamlining of the state administration, and of course eventually maybe even higher pensions, because really enormous billions will be saved; there may be even higher support for people with disabilities, and we want all that.

Dominik Feri: If the Senate is dismissed, every pensioner will receive 20 crowns per month, so in fact it isn't entirely reasonable to dismiss the Senate and use savings as the reasoning

Tomio Okamura: So you may have not listened to me properly, and it is really necessary to learn it - I have written a book about it and it has been quite successful - that in the countries that have strengthened the elements of direct democracy, and it differs in individual states of the USA and from one canton to another in Switzerland, so in places where these elements are strong, the states are more economical and even the states are less indebted

\subsection{Verbal Aggression in the Online Environment}

Verbal conflicts and attacks against communication partners in the environment of online communication were different from those taking place in face-to-face communication. Communicants took advantage of the anonymity of the Internet environment (frequently did not even use their own name, and signed their statuses with nicknames in this particular case e.g. Pěknej kluk [Handsome Boy], Mylouš Jakeš [a mocking reference to the communist politician Milouš Jakeš], em Lexa, etc.). A frequent strategy was instant, impulsive and rather vehement reaction to the shared content, because the authors of the comments were not inhibited when expressing critical evaluations by concern about the potential reaction of the communication partner. Similar derogatory and offensive comments (so-called flames, in greater detail cf. Lehti et al. 2016, online) may even emerge in common straightforward communication, but in the face-to-face form of communication, the communicants are restricted by the tendency to avoid significantly harming strategies because in such cases revenge from the communication partner is expected. Harming strategies may receive a response even in online discussions but regarding the communicative context, the risk of losing one's face is minimal and the harm is only symbolic.

There were 24 comments published in the discussion to the analysed debate and only half of them received replies. In addition, the communication exchanges confirmed the tendency not to develop the discussion (see Lehti et al. 2016, online). The authors of the original comments usually did not react in any way to a reply, which seems to indicate that they did not feel the need to advocate their opinion any further:

[9] pan Hvížd’alák

In real democracy, a referendum should go without saying. It is no matter for discussion here. Those afraid of referenda surely know why they are afraid... don't you, politicians? Because it could happen that the "mob" could prevent you from clinging to 
power and thwart your plans, or rather to the puppeteers controlling you... I hope SPD will succeed in passing the referendum act. Fingers crossed!

Jan Pavel

Clever and educated people are afraid of referenda because there are many times more undereducated manual workers, and it is particularly this idea that manual workers should decide about our future that scares me! ${ }^{8}$

eM Lexa

Mister Clever, and the fact that the majority of the Government are dilettantes is okay with you? ??

In this specific type of social interaction, the communicants seemed to participate in order to express their opinion to the politicians, or the political situation; they did not feel the need to react to others or persuade them about their own opinions.

With regard to the aim of this paper, the investigation into the published statuses was focused primarily on aggressive communicative strategies. It turned out that the communicants who participated in the discussion did not attack the face of their communication partners not even when their political opinions were different. In the vast majority of cases, the target of their attacks were the two politicians whose media appearance they were commenting on; comments attacking the voters with a different political opinion were rare: Mylous Jakes: only an idiot could still vote for Kalousek's party.

The overwhelming majority of negative comments were targeted against Dominik Feri, and were based on ad hominem argumentation attacking the politician's education (one case) and his insufficient political competences (three cases). His lack of experience and incompetence were often placed into contrast with Tomio Okamura (four cases; Erik Konečný: In contrast with Feri, Tomio stands out even more. So, Dominik, come more often; as a »democracy« comedian you are really goooood:-)). The participants in the discussion mentioned the politician's age as a weak point (two cases), as well as his appearance (four cases). Also, these type of comments clearly implied a racist undertone:

8 The comments did not undergo linguistic correction [in Czech; the English translation reflects the nature of the original comments as well].
$[10]$

\section{ZBYNEK ČERNY}

Thievish Monkey from TOP 09

$[11]$

zhnapp

feri looks like a devil, ugh

Bobika Bobota

and the other one is a real thing of beauty

eM Lexa

you've got the point

Honzik Smesny

sir, this seems like racism to me

$[12]$

Paul Katzchen

Please, can someone explain to me why that person, a representative of top-level Czech politics, has not groomed his afro hair. Or maybe he does not feel like a Czech but an African-American coming from Harlem. Who is he actually representing with this appearance?

Lukáš Novák

So that's a really classy argument $(;) ;-;$

Honzik Smesny 2 months ago

While Mr. Okamura is also such a true Czech

Racist comments met with reactions from other communicants who realized their zero argumentation value. In two comments, the criticism of Dominik Feri was connected to criticism of Czech Television - the communicants pointed out that in their opinion the broadcasting station favours the political party which Feri is affiliated with (And then say that ČT does not favour TOP 09. For what other reason would they invite such people like Mr. Feri?). Comments attacking Dominik Feri also included vulgarisms (Tom, is it clear to You that you are talking to two idiots where every word is in vain, in four years they will be gone).

Non-objective argumentation is, however, also typical in comments attacking Tomio Okamura. There is only one status where its 
author reacts to Okamura's television appearance and tries to matterof-factly disprove his claims:

[13]

[...] And let's review it once again - who pushed the adoption of the Treaty of Lisbon, and as a Senator wanted to sue Klaus at the Constitutional Court for refusing to sign it? Yes, Okamura. Tomio Okamura. And also, I'm interested if there is any verification of the claim that Masaryk wanted direct democracy. Masaryk considered direct democracy to be an ideal, but (that is what Okamura omits) he said: "concerning the increasing number of all nations and states, democracy can only be indirect, executed by representatives elected by voters - by the Parliament elected through universal suffrage.

There was a minority of authors of comments aggressively attacking Tomio Okamura; the discussion included four comments targeted against the politician (other were reactions to the comments targeted against Dominik Feri), but with the exception of the status cited below (15), the authors were much more vulgar than those commenting on Dominik Feri:

[14]

Bobika Bobota

okamura is the biggest idiot in the history of japan czech relations

\section{[15]}

C-CIGAN \& DRD KONFLIKT

If he could dismiss the senate, he could also dismiss even the chamber of deputies president and could hand the czech republic over to another country, he really is pitomio [a scornful nickname, roughly equivalent to dumbio], he says bullshit, so let them do politics for free, and let him be the first one idiotenko.

There were only three cases of neutral comments or comments based on ad rem argumentation in the entire discussion.

When the authors of the posts entered a specific type of virtual social interaction, they communicated with other participants, unfamiliar to them, in a way that often resembled a private conversation of people familiar with each other:

[16]

Peter Jóba

Okamura speaks well. If only we had such a politician in Slovakia. And that bogeyman, beyond shame, but we will vote even for such. What else can we do. yung dagger dick

Peter Jóba is one Nazi not enough for you

Bobika Bobota

go have your eyes checked and stop philosophizing

An unofficial private conversation, however, commonly takes place face to face, and an important aspect in its interpretation is the nonverbal message. This deficiency emerging in mediated contact was often reflected on by the communicants: they complemented their messages with emoticons and other graphic features to compensate for the lack of nonverbal means of expression:

\section{[17]}

\section{Pěknej kluk}

Okamura, go and see your psychiatrist. And they do not work for public money unlike politicians (:):-(:):-: Okamura, and then what have you been for seven years now? Aren't you a politician with an exorbitant salary and an office car even with a driver!!?

Conclusion: The investigation of analysed materials showed that aggressive and harming strategies are typical not only for communication of professional politicians, but also for communication in the anonymous environment of an online discussion.

Communication of professional politicians is influenced by the common standard of a communicative event. The politician uses the space provided to him/her within a public appearance to build, or strengthen his/her own positive face. For this purpose, it is important to create or strengthen the negative face of a political opponent. If the success of individual politicians could be measured with the reactions of spectators within an Internet discussion, an interesting observation would be that a politician who used ad rem argumentation and provided specific facts was evaluated negatively, while a politician who normally used false and non-objective strategies and built his argumentation on the stereotypical repetition of a false premise was accepted mostly positively and received the majority of positive comments. 
The relatively new communication environment of online discussions allows participants to express critical attitudes anonymously, which leads to a greater amount of openly offensive strategies (including rude and vulgar expressions). The participants of the communication, who are anonymous and do not risk losing their face in an open confrontation, openly attack the personality traits of politicians that are only loosely, if at all, connected to the execution of their public political function.

\section{Sources}

Duel o referendu - Tomio Okamura vs. Dominik Feri, 26.03.2018. Online: https://www.youtube.com/watch?v=MW0Nr7D7AYs\&feature=youtu.be\&t $=53[$ cit. 27.03.2020].

\section{References}

B r o w n P., L e v i n s o n S., 1987 [1978], Politeness. Some Universals in Language Usage. Cambridge: Cambridge University Press.

B u b 1 it z W., 2009, Englische Pragmatik. Berlin: Erich Schmidt.

C u l p e p e r J., 1996, Towards an Anatomy of Impoliteness. „Journal of Politeness Research" 25, p. 349-367.

$\mathrm{Cu} l \mathrm{p}$ e p e r J., 2008, Reflections on Impoliteness, Relational Work and Power. In: D. Bousfield, M. Locher (eds.), Impoliteness in Language. Studies on its Interplay with Power in Theory and Practice. Berlin: Mouton de Gruyter, p. $17-44$.

C u 1 p e p e r J., 2011, Impoliteness. Cambridge: Cambridge University Press.

G off m a n E., 1967, Interactional Ritual: Essays on Face-to-Face Behavior. Garden City, NY: Doubleday.

Gri c e P., 1975, Logic and Conversation. In: P. Cole, J. L. Morgan (eds.), Syntax and Semantics. Volume 3: Speech Acts. New York-San Francisco-London: Academic Press, p. 41-58.

K a s p e r G., 1990, Linguistic Politeness: Current Research Issues. „Journal of Pragmatics" 14(2), p. 193-218.

K a s p e r G., 2009, Politeness. In: S. D'hondt, J. O. Östman, J. Verschueren (eds.), The Pragmatics of Interaction, Amsterdam: John Benjamins Publishing Company, p. 157-173.

L a k off R. T., 1973, Language and Woman's Place. New York: Harper.

Lak off R. T., 1990, Talking Power. The Politics of Language in Our Lives. Glasgow: Harper Collins.
L a k off R. T., 2012, Conversational Logic. In: J. Verschueren, J. O. Östman (eds.), Key Notions for Pragmatics. Amsterdam-Philadelphia: John Benjamins, p. $102-113$.

L e e c h G. E., 1980, Explorations in Semantics and Pragmatics. Amsterdam: Benjamins

L e e c h G. E., 1983, Principle of Pragmatics. Oxford: Longman.

L e e c h G. E., 2014, The Pragmatics of Politeness. Oxford: Oxford University Press.

Lehti L. et al., 2016, Linguistic Analysis of Online Conflicts: A Case Study of Flaming in the Smokahontas Comment Thread on YouTube Online: http://widerscreen.fi/assets/Lotta-Lehti-et-al2-1-2-2016.pdf. [cit. 17. 03. 2019].

L o c h e r M. A., Watts R. J., 2005, Politeness Theory and Relational Work. , Journal of Politeness Research" 1, p. 9-33.

L o r e n z K., 1969, On Agression. New York: Hartcourt, Brave and World.

N a k o n e č ný M., 1999, Sociálni psychologie. Praha: Academia.

$\mathrm{S} \mathrm{p}$ e $\mathrm{n} \mathrm{c}$ e r - O a te y H., 2007, Theories of Identity and the Analysis of Face. „Journal of Pragmatics" 39(4), p. 639-656.

S pe r b e r D., Wills o n D., 1986, Relevance. Communication and Cognition. Cambridge, Massachusetts: Harvard University Press.

Š v a nd ová B., 1999a, Argumenty a logika. In: M. Jelínek, B. Švandová a kol., Argumentace a uméní komunikovat. Brno: MU, s. 101-134.

Š v a n d o v á B., 1999b, Chybné argumenty (fallaciae). In: M. Jelínek, B. Švandová a kol., Argumentace a uméní komunikovat. Brno: MU, s. 135-184.

W a $t$ t s J. R., 2003, Politeness. Cambridge: Cambridge University Press.

Zí t k o vá D., 2008, Komunikačni prristup ke zdvořilosti a jeho aplikace na reklamni texty. Liberec: Bor. 